\title{
COUNTY HOME RULE IN CALIFORNIA: THE LOS ANGELES COUNTY CHARTER
}

\author{
By LEWIS R. WORKS,
}

Member of the Board of Freeholders that framed the Home Rule Charter for Los Angeles County.

Officially, the movement for county home rule in California had its inception in the initial message of Governor Hiram W. Johnson to the legislature, in January, 1911. The new executive, responding to the popular feeling which had placed him in his pasition, pointed out in the message many reforms designed to better the machinery of government and place it more nearly in the hands of the people. Among these, he suggested such changes in the state constitution as would enable the electors of the respective counties to adopt a form of government for themselves. The message recognized the fact that, to a great extent, counties are agencies for the discharge of state functions and that, therefore, a state cannot grant to its counties the measure of local self-control which it may properly allow its cities. The legislature was accordingly advised to propose to the electorate a constitutional amendment providing for county charters covering a limited range of subjects.

An amendment closely following the suggestions of the governor was adopted by the legislature and was submitted to the people at the special election of October 10,1911. ${ }^{1}$ The amendment was approved and at once went into effect.

Under the new amendment a charter for a given county is to be prepared by a board of fifteen freeholders, themselves first elected by the people of the county at a special election called for the purpose. The election may be held pursuant to ordinance passed by the board of supervisors, a body which is the counterpart of the board of county commissioners in other states, or by initiative petition signed by fifteen per cent of the qualified electors. It is required that the freeholders shall complete and file a draft of a charter within one hundred and twenty days after the official declaration of their election. The proposed charter must then go through a ten days'

${ }^{1}$ At which were also presented twenty-two other measures, including the initiative, referendum, recall, equal suffrage and other amendments. 
publication and must be submitted to the electorate of the county not less than thirty nor more than sixty days after the completion of publication. It must then be adopted by a majority of the votes cast. Before it becomes finally operative it must go to the legislature, at the next session after its adoption by the electors, for ratification.

It is made mandatory upon the people, by the constitutional provision, to incorporate certain features in their county charters.

The constitution is to the effect that charters shall provide:

1. For boards of supervisors and for the constitution, regulation and government thereof, for the times at which and the terms for which the members of said board shall be elected, for the number of members, not less than three, that shall constitute such boards, for their compensation and for their election, either by the electors of the counties at large or by districts; provided, that in any event said board shall consist of one member for each district, who must be a qualified elector thereof; and

2. For sheriffs, county clerks, treasurers, recorders, license collectors, tax collectors, public administrators, coroners, surveyors, district attorneys, auditors, assessors and superintendents of schools, for the election or appointment of said officers, or any of them, for the times at which and the terms for which, said officers shall be elected or appointed, and for their compensation, or for the fixing of such compensation by boards of supervisors, and, if appointed, for the manner of their appointment; and

3. For the number of justices of the peace and constables for each township, or for the number of such judges and other officers of such inferior courts as may be provided by the constitution or general law, for the election or appointment of said officers, for the times at which and the terms for which said officers shall be elected or appointed, and for their compensation, or for the fixing of such compensation by boards of supervisors, and, if appointed, for the manner of their appointment; and

4. For the powers and duties of boards of supervisors and all other county officers, for their removal and for the consolidation and segregation of county offices, and for the manner of filling all vacancies occurring therein; provided, that the provisions of such charters relating to the powers and duties of boards of supervisors and all other county officers shall be subject to and controlled by general laws; and

5. For the fixing and regulation by boards of supervisors, by ordinance, of the appointment and number of assistants, deputies, clerks, attaches and other persons to be employed, from time to time, in the several offices of the county, and for the prescribing and regulating by such boards of the powers, duties, qualifications and compensation of such persons, the times at which, and the terms for which they shall be appointed, and the manner of their appointment and removal; and

6. For the compensation of such fish and game wardens, probation and other officers as may be provided by general law, or for the fixing of such compensation by boards of supervisors. 
In addition to these positive requirements, the constitution permits county charters to provide, also:

For offices other than those required by the constitution and laws of the state, or for the creation of any or all of such offices by boards of supervisors, for the election or appointment of persons to fill such offices, for the manner of such appointment, for the times at which and the terms for which such persons shall be so elected or appointed, and for their compensation, or for the fixing of such compensation by boards of supervisors.

For offices hereafter created by this constitution or by general law, for the election or appointment of persons to fill such offices, for the manner of such appointment, for the times at which and the terms for which such persons shall be so elected or appointed, and for their compensation, or for the fixing of such compensation by boards of supervisors.

The constitutional amendment also provides, in a paragraph too lengthy to be quoted with profit, that the charter may make provision for the construction, care, maintenance, repair, inspection and supervision of roads, highways and bridges, with certain limitations as to the formation of districts and the voting of bonds, for such purposes.

The movement for a charter for the county of Los Angeles was inaugurated by the county board of supervisors. A resolution was passed by that body in March, 1912, requesting the Los Angeles Chamber of Commerce, the leading unpartisan civic organization of the county, to take measures for the nomination of fifteen candidates for freeholders. The chamber accordingly issued a call for a convention to be composed of delegates from the various civic bodies of the county. The response was immediate and the convention speedily held. The list of proposed nominees, completed and adopted by the convention on April 2, was formulated in such manner as to give representation to all parts of the county. From the standpoint of political complexion, the ticket was as happily selected. The list was made up of seven progressives, four republicans, two democrats and two socialists. Taking it from the occupational standpoint, the ticket comprised seven lawyers, three financiers, two business men, one educator, one farmer and one musician.

The convention named a committee of twenty-five to circulate petitions among the people for the formal nomination of the fifteen persons selected. Their names were thus placed upon the ballot and they were elected as a board of freeholders at a special election held May 14. 
At the inception of their work, which was begun immediately, the freeholders found it necessary to consider most carefully the scope of their prospective labors. They were entering upon a virgin field of endeavor. Their efforts, if well directed, were to lay a foundation for the eradication of the glaring evils of the system of county government prevailing throughout the Union. They realized that they could not carry the work to the limit which some of them desired and that they must, at the outset, take strict account of the limited range which their operations might cover as compared with the broad field they could enter upon if engaged in the preparation of a city charter. Most of the members had enjoyed more or less experience in the work of city charter making and they felt themselves almost subconsciously tempted to regard their impending labors in the light of that experience.

The law committee of the board was accordingly directed to examine into the considerations just mentioned. It did so and presented a report to the following effect:

1. The constitutional amendment allowing the formation of county charters provides that a charter "shall supersede all laws inconsistent with such charter relative to the matters provided in such charter." Under this language you are advised that a county charter, although allowed to cover but a limited range of subjects, will, if properly drawn, and within such range, supersede all legislative enactments upon the same subjects; provided, however, that this rule is limited by what is said in the next succeeding paragraph, numbered 2 .

2. It is provided, by a certain paragraph of the constitutional amendment, which paragraph is numbered 4 , that county charters shall provide, among other things, "for the powers and duties of boards of supervisors and all other county officers." Further down in that paragraph, however, occurs the following: "Provided, that the provisions of such charters relating to the powers and duties of boards of supervisors and all other county officers shall be subject to and controlled by general laws." The insertion in the constitution of the proviso, or clause, just quoted, makes it necessary for us to advise you as follows:

(a) A county charter may contain such provisions as the people see fit to insert with relation to the "powers and duties of boards of supervisors and all other county officers," if such provisions contravene no principle of constitutional law, and notwithstanding such provisions are inconsistent with or are in addition to provisions contained in legislative enactments.

(b) If, however, a county charter contain provisions as to such "powers and duties," which provisions are inconsistent with existing legislative enactment, then and in that event, such provisions of the charter would be inoperative, would rest in a state of suspension, during the existence of such legislative enactment, but would become effective or operative upon a repeal of such legislative enactment by the legislature. 
(c) Also, all provisions of a county charter as to such "powers and duties" would become inoperative, would be placed in suspension, even if the same had theretofore been in actual operation, by the passage at any time, by the legislature, of any statute concerning such "powers and duties," such statute being inconsistent with such provisions of such charter, the latter being placed in suspension by such statute only to the actual extent of the inconsistency between the two.

3. The constitutional amendment contains the following: "It shall be competent in all charters framed under the authority given by this section to provide, in addition to any other provisions allowable by this constitution, and the same shall provide, for the following matters," and this language is followed by a specification of the matters referred to. You are advised that the language quoted is mandatory, in the legal sense, and that the charter should contain provisions as to all the matters mentioned.

4. The constitutional amendment also contains the following, below the matters mentioned in the last preceding paragraph, numbered 3, to wit: "All charters framed under the authority given by this section, in addition to the matters hereinabove specified, may provide as follows," and this language is followed by a specification of certain designated matters. You are advised that the language quoted is directory, in the legal sense, and that the charter may or may not, without affecting its validity, contain provisions as to the matters, or as to any of the matters, designated below such quoted language.

5. You are advised that the charter may contain such provisions as conform to the language of the constitutional amendment, for the construction, care and maintenance of roads, even though such provisions conflict with the provisions of the political code or of other general laws, and such provisions will supersede the provisions of the political code or of such other general laws. The matters stated in this paragraph numbered 5 furnish but a specific application of the general principle announced in paragraph numbered 1 of this report.

6. You are advised that the charter may prescribe the number and define the extent and boundaries of each of the districts from which a supervisor is to be nominated as provided in the constitutional amendment.

Taking this report very largely as a basis the board proceeded to the completion of its task. The finished charter was filed within the time prescribed in the constitution. The instrument is remarkable for its brevity. It comprises but fifty-seven sections, with not much more than seven thousand words in all, of which more than one-fourth is given to the civil service article and more than oneeighth to the provisions for the recall. It would be inappropriate here, notwithstanding it is so brief, to present anything like a complete résumé of the provisions of the charter. Endeavor need be made only to show the important features of the work. This can best be done by statements comparing conditions under the general 
county government law of the state with those provided for in the new instrument. Such a comparison is here attempted:

1. Under the state law, all of the important county officers are elective. Under the charter, only the supervisors-who must be elective under the constitution-the sheriff, the district attorney and the assessor are to be chosen by the people. The officers removed from the elective to the appointive list are the auditor, the coroner, the county clerk, the public administrator, the recorder, the surveyor, the tax collector and the treasurer. These will be appointed by the supervisors, but all are to be selected from the eligible civil service lists.

2. Under the state law, the legislature prescribes the number of deputies, clerks and attachés in the various offices. Under the charter, the number will be fixed by the supervisors. The same statement is true as to the number of justices of the peace and constables in the several townships.

3. Under the state law, justices of the peace and the constables are elective. Under the charter, the justices remain elective, but the constables are made appointive by the sheriff, selection to be made from the eligible civil service lists.

4. Under the state law, the sheriff and constables are independent of each other and have been at constant warfare, though their duties were about the same. Under the charter, the constables are made deputy sheriffs, ex officio, and constitute a constabulary department, with the sheriff at its head.

5. Under the state law, all salaries, even those of the deputies and clerks in county offices, are fixed by the legislature. Under the charter, all salaries, even those of the few elective officers, except the salaries of the supervisors, which are stated in the charter, will be fixed by the supervisors. This does not include, however, salaries of officers and employees of the civil service commission.

6. Under the state law, the elective list is long and all officers, except the supervisors whose terms overlap, go out quadrennially at the same time. The county ballot is therefore so long as to be fearful to contemplate. Under the charter, because of a short elective list and biennial elections of part of the officers, all of whom hold office for four years the advantages of the short ballot are secured.

7. Under the state law, certain county officers and also the 
constables in the townships, collect fees for service rendered, which fees are retained by them as the whole of or a part of their compensation. Under the charter, all fees must be turned in and compensation for officers is by salary only.

8. Under the state law, each supervisor is in charge of road construction and maintenance in his district and is therefore to a great extent an itinerant officer. His activities as a member of the county governing board are thus greatly hampered. Under the charter, all the roads are placed in charge of a new officer, the road commissioner, who is to be appointed by the supervisors from the eligible civil service lists. The road commissioner is to act under rules and regulations prescribed by the board of supervisors.

9. Under the state law, civil service regulations are unknown. The charter provides an exhaustive civil service plan, to be under the direction of three commissioners who are to be appointed by the supervisors for six-year terms, one retiring at the end of each two years. The independence of the civil service department is secured by the apportionment to it, by positive charter provision, of a certain part of the annual tax levy. The members of the civil service commission are to fix all salaries of officers and employees in the department. The civil service provisions allow but a very limited unclassified list.

10. Under the state law, there is no provision for an Efficiency Bureau. The charter provides for a complete efficiency system, under the direction of a bureau composed of the auditor and the three members and the secretary of the civil service commission.

11. Under the charter the supervisors are "to provide, publish and enforce a complete code of rules, not inconsistent with general laws or this charter, prescribing in detail the duties, and the systems of office and institutional management, accounts and reports for each of the offices, institutions and departments of the county." The state law contains no such provision. Aside from the work to be done by the Efficiency Bureau, the clause just quoted furnishes the main "publicity" feature of the charter.

12. Under the state law, the recall is limited to elective officers. The charter extends its operation to appointive officers. It cannot be invoked as to such officers under civil service, however, until after unsuccessful demand for removal, addressed to the civil service commission. 
The charter was submitted to the people of the county at the general election in November, 1912, and was adopted by a handsome majority. It received the approval of the legislature in January, 1913, and became, through that sanction, the organic law of the county. It goes into operative effect on the first Monday in June, 1913.

Notwithstanding the limited range allowed to the operation of county charters under the constitutional amendment, the new instrument has, without doubt, set a stake far forward in the solution of the vexing problem of county government in the United States. The framers of the charter had a high sense of the importance of the work committed to their care and pursued it with a noteworthy degree of genuine patriotic fervor. The spirit behind the labor was beautiful to contemplate, and its existence justifies the assertion that the framers made a wordless, but nevertheless actual, dedication of their work, not alone to the people who are to live under it, nor to the people of California, but to the people of the entire United States. 